\title{
THE LAW AND QUESTION. THE PHENOMENON OF QUESTION AS A POSSIBLE POINT OF DEPARTURE FOR THE PHENOMENOLOGICO-GENETIC THEORY OF LAW
}

\begin{abstract}
In his original phenomenology of law Adolf Reinach distinguishes among experiences the so-called "social acts". These include acts directed towards other persons that require that the latter acknowledge the communicated contents and assume certain attitudes. Among these acts Reinach mentions there are promises, orders, requests and questions. He argues the promise is the special act that creates the a priori grounds of law. It is to be noted that Reinach's phenomenology of law is of static character (in the Husserlian sense of the word) and therefore it shares all its advantages and disadvantages.

In my paper I would like to draw attention to another social act, which can also be attributed to certain law-making activities, especially from the perspective of the genetic phenomenology. It is questioning. At the same time when Reinach was working on his theory of law, his Munich friend, Johannes Daubert (1877-1947), also a student of Theodor Lipps and a friend of Edmund Husserl, who together with Reinach made an "invasion of the Munichs at Göttingen", worked on the first phenomenology of the question. Although he did not refer his research to the phenomenon of law, we can ask whether, like Reinach's deliberations about promises and obligation, it cannot be done. That this is possible to some extent, for example, is evinced by the Hannah Arendt and Klaus Held's phenomenology of the political world. He points out that the public world as such arises from the primordial openness of man, understood as "zoon politikon". This openness might be interpreted as the question which is not so much a single act as it is an attitude.

The purpose of the paper is to outline how, while starting with the phenomenological reflection over various types of utterances, one can specify their certain forms and the acts constituting them as well as the attitudes which allow for a priori grounding the phenomenon of law from the perspective of static and genetic phenomenology.
\end{abstract}

Keywords: Adolf Reinach, phenomenology of law, question.

\section{INTRODUCTION}

The work of Adolf Reinach entitled Die apriorischen Grundlagen des bürgerlichen Rechtes is subsumed under a wide array of phenomenological works, the influence of which were further reaching than the school of phenomenology itself. The a priori theory of law presented therein counts as the "regional ontology". What is meant precisely thereby is a phenomenological theory of

\footnotetext{
*Polish Academy of Sciences, dsobota@ifispan.waw.pl
} 
law - that is, pure jurisprudence. In Reinach's opinion, legal entities are granted the same sort of independent existence as "numbers, houses and trees"; and principles that regulate the order and interdependencies of the said laws are of a priori and essential nature (Reinach 1913, 68-689). ${ }^{1}$ The phenomenology of law investigates the so-called primary concepts, which delineate the extension and the essence of what is known from the experience in the form of a positive law, laws of nature and human rights etc. Both the realm of positive law and some extra-positive-law realities assume and make ample use of the said primary concepts. Still, it does not entail that between said legal entities, the essence of which was examined by Reinach by virtue of intuitive insight, and positive law, the historical heterogeneity of which is evidenced by numerous historical codes, there is a direct 'bearing'. Such a relation between ideal entities (and a priori laws describing them) and real entities holds only in mathematical natural science, logic and mathematics. Between legal entities and positive law, there indeed holds a significant relationship; however, it is not the case that only positive law may be referred to as law in a paradigm sense, the contents of which corresponding with the contents of ideal legal entities. The historical variety of legal reality evidences something quite the opposite. Reinach speaks of 'the independence of positive law with respect to the apriori theory of right' (Reinach 1913, 691; Reinach 1983, 6), and of the 'freedom' of positive law (Reinach 1913, 692; Reinach 1983, 67). He explains that "only this (...) makes understandable why certain legal institutions have developed so slowly and with such difficulty" (Reinach 1913, 692; Reinach 1983, 67). Between the actually binding law, which may be posited without making any effort to take into consideration an essential content of ideal legal entities, and the latter, that is ideal legal entities, there is a difference that is much more glaring than the difference between the ideal content of mathematical states of affairs and the mathematical entities resorted to while doing a particular exercise of calculating. Existence as such further specifies what is essential, adding to it not only accidental elements, being enabled by what is essential. However, in case of positive law, an actually positive law may stand in "opposition" to what is essential (Reinach 1913, 690; Reinach 1983, 6). ${ }^{2}$ The occurrence of positive law gives rise to such a disparity between an a priori order and an empirical one that is unknown in the realm of natural-science or mathematical entities. What is this "existence" in case of legal reality?

We can say that it is the existence of a human, the said existence being characterized by freedom. It is precisely the condition of freedom that makes a man in his or her individual existence be indeterminate, unpredictable. Existing in this mode, a human being creates his own reality, is referred to as history. In the

${ }^{1}$ In the forthcoming part of the paper, we shall quote the particular pages of the German edition, while indicating the pages of the corresponding English edition.

${ }^{2}$ The nature of this opposition is elucidated by Reinach in the concluding parts of his work: Reinach (1913, 802; 1983, 102 and others). 
said work, Reinach does not take up this broad context of human life, within which a phenomenon of law does appear. Still, it does not mean that it is absent from his considerations. Unlike Husserl, who focused his investigations on phenomena from the area of logic, formal ontology or epistemology, the investigations being conducted either in a "lonely life of soul" or as a process of constitution in transcendental subjecthood, Reinach studies the essence of experience related to the actual world and people (the evidence of which are - among others - numerous references made to the German law being operative at that time). Whereas Husserl in his writings demanded that the thesis of the existence of the world (and of himself and other people) be bracketed, the investigations conducted by Reinach, though oriented at the study of essence, still operate in the realm of actual reality, the tangible existence thereof sort of permeates through the eidetic description. Husserl was from the very beginning focused upon the realization of such a phenomenology that would first stand up to the problems of logic, formal ontology and epistemology. It is precisely these problems that Husserl dedicated almost all of his published works to.

It was only as time went by and only in his 'private' investigations (perhaps he was motivated by what was going around him at that time) that he devoted more attention to these phenomena that were not directly related to his searching for the solutions to theoretical epistemological problems. Reinach recorded the attempts at facing the problems pertaining to logic (a theory of proposition), see: Reinach (1989, 339-345, 347-350), and to natural science (the problem of motion), see: Reinach $(1989,551-588)$. However, in the spirit of realist phenomenology, he was - as many other phenomenologists - particularly interested in those phenomena which are closer to a human being inhabiting the world of natural attitude. In comparison with Husserl's phenomenology, being oriented at seeking for absolute truth and constructing a system of sciences and saving humanity, at incessantly searching for "proper" phenomenology - this sort of comprehensive and fundamental considerations I should like to label as macrophenomenology - Reinach's considerations, like other followers of Husserl from Munich and Göttingen, were concentrated on more modest and more local issues - without the need to ceaselessly redefine what phenomenology is as such within the context of the fundamental problems of philosophy. This in turn rather constitutes microphenomenology, which is far from pompous overtones of Husserl and Heidegger. ${ }^{3}$ Still, it does not imply that Reinach's phenomenology resigns in its scope from maximalist ambitions of phenomenology as such. Although the determinations phenomenologists arrived at while conducting their respective research have all far-reaching, oftentimes revolutionary, consequences for the understanding of elementary philosophical and phenomenological problems

${ }^{3}$ The distinction between micro- and macrophenomenology resembles the difference between micro- and macroeconomics. Still, we should treat this analogy with caution. 
such as being, cognition, human being, consciousness, truth or language, with the determinations not going thus far and not explicitly announcing the reached general conclusions, they do not seem to overburden or call into question the Husserlian methodological framework adopted. Still, it transpires that the 'anomalies' accumulating over time at the level of regional investigations finally cause the collapse of the Husserlian vision of epistemological phenomenology. Therefore, for the reason of the attitude towards the phenomena studied and for the reason of the very choice of the problems of law, with law being one of the most significant elements of historical reality of man, Reinach's phenomenology may be regarded as an introduction to a direction the entire phenomenological movement will head for in the near future, with the said direction to be interpreted in terms of further dissociation with the "original" Husserlian phenomenology. What is thereby meant is hermeneutic phenomenology.

\section{THE PHENOMENOLOGY OF NON-PROPOSITIONAL STATEMENTS AND ITS PHILOSOPHICAL CONSEQUENCES}

It is no accident that the shaping of hermeneutic phenomenology is connected with the study of experience not belonging to the realm of pure logic or epistemology. Reinach's investigations of a priori foundations of law constitute a cornerstone of the XX-century theory of speech acts. They revolve around the phenomenon of promise, which he regards as the social act. Let us bear in mind that Reinach is one of the first thinkers who distinguished within phenomenological investigations a group of acts of characteristic-social - nature (Smith 1990, 29-61). Namely, these are active, spontaneous intentional experience which not only has a referential function, but also - in the form of physical act of communication (by dint of language, mimics or gesture) addresses the other person in order to make the latter understand what is being communicated and to invoke in him or her an appropriate reaction. What Reinach subsumes under this category are promises, commands, requests and questions. They all transcend the narrow scope of monological consciousness and assume a wide array of various phenomena among which only a small fraction yield itself to being studied by virtue of acts of cognition. In line with the Aristotelian division - present in his De interpretatione (17a) - of meaningful statements (semantikos) into affirmatives (the ones having truth value) (apophantikos) and those which cannot be ascribed truth value, the speech acts expressing social acts belong to the latter category. Aristotle himself thought that the latter statements cannot constitute a subject matter of logic, which by definition abstracts from specific content, situations and persons making up the process of reasoning. This category of statements rather belongs to the realm of rhetoric and poetics, which must take into consideration both what is talked about (theme), the one who does the talking (rhetorician) as well as the 
persons being talked to (auditorium). In Husserl's Logical Investigations, what is dedicated to studying the justifiability of the said division of speech acts is Investigation VI. According to Husserl, such speech acts as requests, commands or questions neither have truth value, nor do they possess any independent meaning. The latter is ensured to them due to the so-called meaning-granting acts, which in the case of mentioned speech acts - through the process of reflection - refer to respective experiences of requesting, wishing, doubting and consecutively represent these in the form of sentences (Husserl 2009, 749-750). That is why, it is only propositions at the basis of which there are objectifying acts that are of interest to logic and epistemology.

The above-presented Husserlian solution shortly met with criticism. From the very beginning of the phenomenological movement, among Husserl's students what seemed to be of great interest to them were also other experiences than those strictly connected with logic or epistemology. In his theory of law, Reinach paid special attention to the acts of promises. Still, what is worth mentioning is his theory of negative judgments. Reinach's friend, Johannes Daubert, studied the phenomenon of question (Schuhmann, Smith 353-384; Sobota 2018), while Alexander Pfänder studied commands (Pfänder 1982, 287 and others). Apart from that, what was of special interest in phenomenological circles were those forms of speech acts that were related to religious life. Early Heidegger, for example, paid special attention to the phenomenon of foretelling (Heidegger 1995, § 30), whereas Reinach studied the structure of negative statements, premonition and prayer etc. (Reinach 1989, 95-140, 589-593). What comes next are the studies within the scope of literary language, which after all - as any language - resorts to affirmatives; however, they do not express ordinary propositions in a logical sense (Ingarden 1988, § 25).

The said great interest among phenomenologists taken in the problematics of non- and quasi-propositional expressions corresponded with the study over the phenomena which were outside Husserl's interest, and to which the said expressions refer. Reinach's theory of collective acts amounted to - ex hypothesi - the foundation of his phenomenology of law. Pfänder, on the other hand, spoke of a theory of imperative as "Grundwissenschaft for ethics, philosophy of law and pedagogy" (Pfänder 1982, 287). A similarly adventurous early Heidegger's interpretation of Aristotelian Rhetoric served as a foundation of his phenomenological hermeneutics of factual life (Heidegger 2002), while the analysis of the phenomenon of question as such delineated the framework to work out his Seinsfrage (Heidegger 2006, § 2; Sobota 2012; Sobota 2013). On the other hand, Ingarden's theory of quasi-propositions was a point of departure for his ontology of a literary work (Ingarden 1988).

This great interest taken in linguistic phenomena on the verge (or outside of it) of modern logic and epistemology resulted not only in the extension of the phenomenon under scrutiny but also indirectly influenced the reinterpretation of 
the issues within the remit of logic, ontology and epistemology. Allowing for such phenomena as reality, life, intersubjectivity, history, law, feelings, bodiliness, morality, art or religion, what was called into question was the apparent primacy of epistemology in phenomenology, as proclaimed by Husserl himself. What was also altered was the very understanding of phenomenology and its tasks. In the context of the said issues, it transpired that idealistic transcendental phenomenology is unable to do justice to those phenomena; or, to put it bluntly, being oriented at other goals - that is epistemological ones - it is harassed by falsities and disfigurements.

\section{INVESTIGATING THE A PRIORI FOUNDATIONS OF LAW VS THE QUESTION ABOUT ITS A PRIORI ORIGINS THE STATIC AND GENETIC PHENOMENOLOGY OF LAW}

That is why Reinach's phenomenology may be regarded as one of the expressions of the tendency for phenomenology to hermeneutize itself, the tendency being present since the emergence of the phenomenological movement in Munich. The very choice of the subject matter, that is the phenomenon of law, suggests to us that Reinach was visibly departing, being at the same time applauded by his promotor, from the scholarly interests manifested in Husserl. When Reinach states that at the basis of law there are no objectifying acts but only social acts and that law does not consist in judgements but rather in precepts which do not have truth value, he is thus situating his area of study beyond the remit of logic and makes it thereby closer to rhetoric and hermeneutics. There is nothing surprising about it, since for a very long time now these two realms have been closely connected with the phenomenon of law. The first ancient rhetoric principles emerged as the principles related to judicial speeches. Greek rhetón denoted a strictly and clearly formulated legal norm (Korolko 1990, 34). Also hermeneutics, which carries the legacy of rhetoric, regards the domain of law as a paradigm model of hermeneutic experience (Gadamer 1990, 333-334).

Among the above-mentioned phenomena of social acts, Reinach, for his a priori theory of law, picks up promises as a subject of scrutiny. According to him, what counts as the essence of promise is both a claim and an obligation, with this combination constituting the substance of legal entities. And it holds true regardless of who makes a promise. Says Reinach, "in whatever person a promise is realized, whether it is angels, or devils, or gods who promise to each other, claims and obligations arise in the angels, devils, and gods - as long as they can really promise and can hear promises. (...) The nature of the performing subject is evidently irrelevant for the essential relations" (Reinach 1913, 741-742; Reinach 1983, 47). At this point, one may ask if it really is the case that whoever promises or obligates himself really does not matter for the law to be constituted. Moreover, is it the case that various modes of existence and of conduct that we 
attribute to persons are insignificant when it comes to the law being constituted? Is it possible to totally skip the existential perspective (who?) without doing any harm to the understanding of what law is? What Reinach fails to address in his considerations is an issue why and how law emerges from the acts of promises which human persons make. Instead, he studies law as an already existing entity. Just as Husserl in his Logical Investigations dealt with the descriptions of the essence of experience lying at the foundation of logical entities, so does Reinach describe the nature of promise, transfer and conferral as a basis of legal entities. Their ultimate source - according to Reinach - is a "fundamental legal capacity or power (Grundkönnen) of the person. This fundamental power cannot be transferred. Insofar as it is grounded in the nature of the person as such, it is inseparable from the person; it forms the ultimate underground (Untergrund), which allows for the constitution of (Konstitution) legal-social relationships" (Reinach 1913, 780; Reinach 1983, 81 - the English translation was slightly modified). However, by virtue of what does law emerge on the basis of this potentia and these acts - this Reinach's phenomenology does not explain. Neither does it explain what a person is, what is his mode of existence and what it means to act. At this point, we encounter the clear limitations of Reinach's theory of law (Crosby 1983, 173). He shares the weaknesses - recognized by late Husserl - of the approach which is labelled as the static phenomenology.

Let us recall some concepts. The static phenomenology is this sort of phenomenology which "normally takes as its starting point a certain universe of objects" - for example, Reinach's phenomenology is centred around the objects of law - "and only then investigates intentional acts with which the former are correlated and by which they are constituted" (Zahavi 2012, 124-125). The static phenomenology studies the modes of constitutions of a certain ontological universe according to the latter's "essential forms". On the other hand, the genetic phenomenology, which complements and specifies the former phenomenology, studies the genesis of the constitution of the awareness of objects, "the constitution of this constitution", the constitution of habituality, and thus of the very capacity or power, which the above-cited excerpt from Reinach refers to. The field of study encompasses passive syntheses and the history of sense-sedimentation. The genetic analysis, unlike the static one, takes heed of time dimension (Płotka 2012, 34-36). At the centre of attention of the former analysis, there appears life-world (Lebenswelt) and history (Geschichte). It must be conceded that the time perspective is in Reinach's phenomenology of law, similarly to Husserl's Logical Investigations, virtually absent. It seems rather peculiar, in particular in connection with promises which are clearly of temporal nature (Nietzsche 1904, 57-61; Ricoeur 2003).

In the meantime, while supplementing Reinach's considerations, it is worthwhile to ask how the process of positing law looks like from the point of view of the genetic phenomenology. Certainly, what is at stake now is not at this moment a complex phenomenological theory of positing law but what is intended 
instead is to pay attention to these most fundamental acts that participate in the emergence of law. What is thereby meant is the question of how law emerges from the dynamics of the lifeworld and human existence. Is there promise among them anymore? Certainly - as demonstrated by Reinach - promise plays the most vital role in the context of what is supposed to get posited. Since it is precisely a promise that delineates the characteristic realm of what is meant by the very process of positing law. Yet, facing the question about this process, what seems to be of greater importance are other acts. Says Chaïm Perelman - "law is shaped by disputes, dialectical contradictions and opposing argumentations" (Perelman 1984, 36). Therefore, it takes place not wherein the essence of particular social acts is respected, especially of a promise, but rather where there is a smaller or bigger discrepancy between efficacy of a duty flowing from the essence of given acts and the factual discharging of a duty in question. The need to positive law does not after all stem from the fact that promises are kept; but on the contrary, that they are broken. And they are broken because man can respect the essence of the acts embarked upon him or her, but by no means must he or she do so.

Man is an animal which is able to make promises (Nietzsche 1904, 57). Yet, if man keeps his promises once a promise has been made, the law would not have emerged in the first place. And this is - among others - what the difference between man and God consists in; that is, when it comes to the latter, "his will is his law"; in the case of man with all his finitude, there is a clear discrepancy between his will and what he actually does or what he ought to do. The basis - or rather: the chasm (Ungrund) - which opens up at the foundations of the very discrepancy in question is human freedom. This, in turn - as Kant said - is marked by a certain sort of weakness; namely, what inheres in it is "a natural tendency to evil" (Kant 2011, 32-45). Evil consists in the reversal of a moral order relative to impulses of free will (Willkür). What the said reversal involves is that the impulses stemming from the moral law are valued less than others (non-moral ones), see: (Kant 2011, 33). In Kant's view, the origins of this tendency is impossible to study (unerforschbar), which implies that such a study would transcend the capacities of Reason. At this point, theology speaks of satan, temptation and the fall of man (Kant 2011, 44-46). Abstracting from mythical ways of understanding human nature and its history, one should rather pursue the path of phenomenologico-genetic illuminations and thus demonstrate the mode of existence of human subjecthood as a free, albeit finite, entity which is internally divided and uncertain. And most characteristically, what inheres in our human nature is the fact that sometimes persons do not keep the promises they make and it is precisely why we need law in the first place. Although, ideally speaking, the law appears to be founded upon the act of a promise; in reality, the reverse seems to be the case: it is the law which somehow forces an act of commitment. Although the life-world (Lebenswelt) is characterized by some peculiar familiarity, it is also marked by immanent uncertainty - a sort of primordial "may be" 
(Husserl 1929, 112-114) . This, in turn, is due to time, the flow of which makes human life transient. Law is a transcendent being which, in the face of freedom and unpredictability of human acts, constitutes a supra-individual and timeless guarantee of the common life-world. It is a manifestation of the common will, which sets limits to arbitrary will.

\section{QUESTIONING AS A PRIMORDIAL SITUATION OF POSITING LAW IN THE PUBLIC SPACE}

Then, the motive for positing law, but also the sense of judicial practice, derives from the discrepancy between the essence of what ought to be and what is in reality. Is there such a type of utterances and of the acts expressed therewith that would be located within the above-specified discrepancy, would express the uncertainty of man's being-in-the-world and at the same time would constitute the behaviour giving rise to law? In Husserl's Ideas I, the description of this discrepancy between an essence and a fact is an overture to the introduction of the mechanism of phenomenological reduction, which he understands in a similar vein as he understands question (Płotka 2012, 311-329). This reduction enables a phenomenologist to discover essential laws. They constitute answers to an essential question "what is it?". This question differentiates (as well as refers to itself) between the essence in question and the entities participating in that essence (Heidegger 2006, § 2). Is it indeed the question that is this distinguished act that participates in creating and respecting law?

Abstracting from these strictly philosophical contexts, it is rather easy to demonstrate great significance and large share of questions in daily judicial practice (Brożek 2007, chapter XVI). But the relation between law and question is ambivalent. It must be granted that Reinach does show that between law in the sense of precepts/enactments (Bestimmung) and the question there are many analogies. However, the ultimate disanalogy is that a precepts/enactments has an utterly distinct (if not contradictory) nature from the one of question. The precepts/ enactments is more of an answer to a question than it is a question itself. Law determines how it is and/or should be, it is a basis for such determinations.

In order to fully answer the query of what is the role of the question in creating and respecting law, one should conduct an analysis of what is the question as such and how it functions in the context of a legal order. Certainly, this cannot be achieved within the limits of one short publication. ${ }^{4}$ That is why, instead of in-depth studies over the question one would be well-advised to turn attention to certain historical circumstances. It happened to be the case that the theme of

${ }^{4}$ The selected works on the phenomenology of the question: Schuhmann, Smith 1987, 353384; Sobota 2018; Ingarden 1972, 327-482; Fales 1943, 60-75; Bruin 2001; Płotka 2012, 69-92. 
the question became a great problem in the early phenomenology due to Reinach's friend Johannes Daubert. Daubert started his studies over the phenomenology of question exactly at the moment when Reinach was working on his theory of negative judgement (1911). As follows from the correspondence between them, Daubert originally reserved the subject matter of negative judgements to himself; however, upon Reinach's request, he returned this topic to the latter, choosing the topic of question to work on instead. The pioneering description made by Daubert can be found in his unpublished legacy, in the folder called Frage, originating from 1911-1912. ${ }^{5}$ The analysis of these notes were conducted by Karl Schuhmann, Barry Smith and recently - by the author of the current presentation (Schuhmann, Smith 1987, 353-384; Sobota 2018). Despite the fact that Daubert is the first one to thoroughly investigate the issue of the question, it is Reinach who first used the phrase Phänomenologie der Frage. In his short essay on reflection, he not only resorts to the phrase Phänomenologie der Frage, but also - in a sort-of implicit discussion with Daubert - he presents his own analysis of the question or rather - a questioning attitude (Fragestellung). ${ }^{6}$ In Reinach's opinion, reflection plays a vital role when it comes both to cognition and to ethics and law. Reflection is constituted by questioning attitude, which aims at finding a solution to the spotted problem. In the said essay, Reinach deals with the phenomenon of reflection in the same way as it takes place in 'lonely life of a soul'. He only mentions the situation of a lecture, in which the reflection is carried out in the presence of other people. The audience then accompanies the lecturer in his questioning attitude, with the audience trying to do the same as the lecturer but in their respective inner selves. Although a lecture may be of an interactive nature, it is normally a monologue. The audience plays a passive role of recipients or of a witness of what is happening. However, in the situation of positing law, the conditions are just the opposite. Abstracting from those historical situations in which law was posited by one person and was promulgated by his subjects, positing law normally takes place during public discussions. And these in turn are a certain interplay of questions and answers.

Putting it that way, the contribution of the phenomenon of question in constituting law shifts our considerations from the narrowly understood phenomenology of law into the phenomenology of the political world. After all, positing law is a political act par excellence. Perhaps, regarding dialogue as a principle of the political world, we narrow the scope of the phenomenon of politics far too much. Still, doing so we follow the footsteps - and rather justifiably

${ }^{5}$ Written mainly by a stenographic method, Daubert's manuscripts and their respective translations into German are to be found in Bayerische Staatsbibliothek in Munich. The file dedicated to the question bear the following signature: Daubertiana A I 2.

${ }^{6}$ See: Reinach $(1989,282)$. The analyses of the question as a social act are also to be found in: Reinach (1913, 709-710; 1983, 21-22). 
so - of Hannah Arendt and Klaus Held, both of whom claim that what constitutes the domain of politics is reflection, receptiveness and questioning.

Let us only recall that in her considerations over human condition, Arendt distinguishes between action which takes place in the public realm from other forms of man's activities which man partly shares with non-human animals. Action constitutes a domain of free and equal individuals who bravely step out of their home-bound privacy only to compete with each other for everlasting glory via "big words" or deeds. The public realm is a place wherein we can witness the tension between contradictory standpoints. Furthermore, the law is also posited there. In Arendt's view, historically speaking, law is operative mainly in the public realm; and only derivatively and to a limited extent - that is due to the nature of the following - it is effectuated in the private sphere. This latter sphere is rather a sphere regulated by daily needs and the arbitrary will of the mighty man (Arendt 1998, subchapter 4-5). ${ }^{\text {? }}$

In the same spirit speaks Klaus Held, being inspired by the works of Husserl, Heidegger and Arendt. He attracts our attention to the link between politics, law and question, thereby referring to what was once labelled as res publica. The last phrase connotes a public affair, that is something one is debating and settles conclusively (Held 2010, 15-16). Ceasing to make use of the means being necessary for daily survival, man reflects upon the future possibilities of action. The said reflection, which Reinach also talked about, takes place not in lonely life of a soul but as a public debate, the collision of attitudes and reasons. It is in the process of a discussion that law is created, the shape thereof - rather similarly to a discussion - never being ultimate, but always provisional. Thus, at the basis of positing law in the public sphere there is the question, which can be understood - after Reinach - as a receptive questioning attitude realized in social acts and shared by all the participants of the political world.

\section{CONCLUSION}

The above-presented considerations do not call into question the conclusions reached by Reinach. Rather, the former appears to complement the latter. After all, it may be the case that among social acts that Reinach spoke about, it is not only promises and questions that are these acts that enable us to grasp the essence and genesis of law. Pfänder mentions the role of a command. However, on this basis, one should recognize that Reinach's theory is incomplete and still requires additional philosophical reflections which, while not resigning from the eidetic approach, are supposed to illuminate the phenomenon of law in its genuine daily functioning. Furthermore, Reinach's theory presupposes the whole spectrum of

${ }^{7}$ On Arendt's philosophy of law, see: Torre (2013, 400-416). 
ontological, anthropological and ethical issues which - due to the requirements of the topic of his monograph dating back to 1913 - were only hinted at by the author. However, they did not get elaborated upon and neither were they further specified. What is thereby meant is the issue of the relation between the ideal and factual, the issue of the existence of a legal and political community, the problem of the existence of the Other, theory of time as well as a theory of personal identity etc.

What craves for getting further specified is undoubtedly also the proposal presented herein. The proposal is that, while not resigning from a priori investigations, one ought to search for the foundations of law not only in the static but also in the genetic order. The question is a phenomenon founded in a multi-fold way, and being also highly dependent on the context in which it appears (who asks?; why does he ask?; whom does he ask? etc.) it cries out for further comprehensive studies engaging many disciplines of philosophy (Sobota 2018). In the context of philosophy of law, what would be the most important is, however, the elucidation of the relation between law and the question. In the above considerations, we paid attention to the role of questioning in creating law. However, the question performs a very important function also when the law has been enacted and must be applied within a given legal reality (Husserl 1929, 129 and others). Therefore, the question relates to the actual existence of law. The problem of application entered philosophical hermeneutics from the realm of law, with philosophical hermeneutics relating the problem of application to the problem of the question (which is done by jurisprudence but even more by philosophical hermeneutics, see: Gadamer 1990, 333-334). So, it transpires that what is commonly regarded as unquestionable and certain - oftentimes even as sacred because stamped with a divine authority - is grounded in a eroteric ${ }^{8}$ context.

\section{BIBLIOGRAPHY}

Arendt, Hannah. 1988. Human Condition. Chicago-London: The University of Chicago Press.

Brożek, Anna. 2007. Pytania i odpowiedzi. Tło filozoficzne, teoria i zastosowania praktyczne. Warszawa: Wydawnictwo Naukowe Semper.

Bruin, John. 2001. Homo Interrogans. Questioning and the Intentional Structure of Cognition. Ottawa: University of Ottawa Press.

Crosby, John F. 1983. "Reinach's Discovery of the Social Acts". Aletheia 3: 143-194.

Daubertiana A I 2.

Fales, Walter. 1943. "Phenomenology of Questions". Philosophy and Phenomenological Research 4(1): 60-75.

Gadamer, Hans-Georg. 1990. Gesammelte Werke. Vol. 1: Wahrheit und Methode, Grundzüge einer philosophischen Hermeneutik. Tübingen: J.C.B. Mohr (Paul Siebeck).

Heidegger, Martin. 1995. Gesamtausgabe. Vol. 60: Phänomenologie des religiösen Lebens. Frankfurt am Main: Vittorio Klostermann Verlag.

\footnotetext{
${ }^{8}$ Greek erotesis means 'question'.
} 
Heidegger, Martin. 2002. Gesamtausgabe. Vol. 18: Grundbegriffe der aristotelischen Philosophie. Edited by Mark Michalski. Frankfurt am Main: Vittorio Klostermann Verlag.

Heidegger, Martin. 2006. Sein und Zeit. Tübingen: Max Niemeyer Verlag.

Held, Klaus. 2010. Phänomenologie der politischen Welt. Frankfurt am Main: Peter Lang.

Husserl, Edmund. 2009. Logische Untersuchungen. Hamburg: Felix Meiner Verlag.

Husserl, Gerhart. 1929. "Recht und Welt". Jahrbuch für Philosophie und phänomenologische Forschung 10: 111-158.

Ingarden, Roman. 1972. Z teorii języka i filozoficznych podstaw logiki. Warszawa: PWN.

Ingarden, Roman. 1988. O dziele literackim. Badania z pogranicza ontologii, teorii języka i filozofii literatury. Warszawa: PWN.

Kant, Immanuel. 2011. Dzieła zebrane. Vol. V. Toruń: Wydawnictwo UMK.

Korolko, Mirosław. 1990. Sztuka retoryki. Przewodnik encyklopedyczny. Warszawa: Wiedza Powszechna.

La Torre, Massimo. 2013. "Hannah Arendt and the Concept of Law. Against the Tradition". Archiv für Rechts- und Sozialphilosophie 99(3): 400-416.

Nietzsche, Fryderyk. 1904. Z genealogii moralności. Pismo polemiczne. Warszawa: Nakład Jakuba Mortkowicza.

Perelman, Chaïm. 1984. Logika prawnicza. Nowa retoryka. Warszawa: PWN.

Pfänder, Alexander. 1982. "Impertivenlehre". In Pfänder-Studien. 287-324. Edited by Herbert Spiegelberg, Eberhard Avé-Lallemant. The Hague-Boston-London: Martinus Nijhoff Verlag.

Płotka, Witold. 2012. "Analiza struktury i geneza egzystencji: dwie postacie metody fenomenologicznej". Kwartalnik Filozoficzny 40(3): 23-41.

Płotka, Witold. 2012. "Co pojęcie pytania wnosi do naszego zrozumienia fenomenologii? Między odnową i herezją". Fenomenologia 10: 69-92.

Płotka, Witold. 2012. "Husserlian Phenomenology as Questioning: An Essay on the Transcendental Theory of the Question". Studia Phaenomenologica 12: 311-329.

Reinach, Adolf. 1913. "Die apriorischen Grundlagen des bürgerlichen Rechtes". Jahrbuch für Philosophie und phänomenologische Forschung 1(2): 685-847.

Reinach, Adolf. 1983. The Apriori Foundations of the Civil Law. Translated by John F. Crosby. Aletheia 3: 1-142.

Reinach, Adolf. 1989. Sämtliche Werke. Textkritische Ausgabe in 2. Bänden. Vol. I: Werke. Edited by Karl Schuhmann, Barry Smith. München: Philosophia Verlag.

Ricoeur, Paul. 2003. O sobie samym jako innym. Warszawa: Wydawnictwo Naukowe PWN.

Schuhmann, Karl. Barry Smith. 1987. "Questions: An Essay in Daubertian Phenomenology". Philosophy and Phenomenological Research 47(3): 353-384.

Smith, Barry. 1990. "Towards a History of Speech Act Theory". In Speech Acts, Meanings and Intensions. Critical Approaches to the Philosophy of John R. Searle. Edited by Armin Burkhardt. Berlin-New York: De Gruyter.

Sobota, Daniel R. 2012. Źródła i inspiracje Heideggerowskiego pytania o bycie. Vol. 1: Neokantyzm i fenomenologia. Bydgoszcz: Fundacja Kultury Yakiza.

Sobota, Daniel R. 2013. Źródta i inspiracje Heideggerowskiego pytania o bycie. Vol. 2: Filozofia życia, filozofia religii i filozofia egzystencji. Bydgoszcz: Fundacja Kultury Yakiza.

Sobota, Daniel R. 2018. Narodziny fenomenologii $z$ ducha pytania. Johannes Daubert i fenomenologiczny rozruch. Warszawa: IFiS PAN.

Zahavi, Dan. 2012. Fenomenologia Husserla. Kraków: WAM. 